DOI: 10.20472/IAC.2018.043.011

FRANK HAGER

University of Latvia - Faculty of Economics and Management, Latvia

\title{
GENDER AND LEADERSHIP - DO FEMALE LEADERS PERFORM A DIFFERENT, BETTER OR EVEN A HEALTHIER LEADERSHIP STYLE?
}

\begin{abstract}
:
Organizations are facing new challenges due to the constantly changing world of work. In addition to technical developments and innovations in work and organizational processes, the human factor is increasingly becoming part of competitiveness. Businesses benefit greatly from their employees, their knowledge and skills during this fast-moving time. Healthy employees are a prerequisite for innovation, progress and growth, which must be protected as part of a sustainable corporate strategy. Thus, in scientific discussions, both, workplace health promotion and healthy leadership are considered to be successful components in dealing with volatile, dynamic and complex conditions. Conduct of executives has a significant influence on the well-being of the employees and thus a direct effect on the company's success. Managers can influence social relationships as well as prevailing work situations - and finally the health status of employees. In occupational science studies as well as in leadership research, the differences in leadership between men and women are analyzed. There are very few studies on healthy leadership that examine gender differences more closely. This paper deals with the question of how gender differences affect leadership behavior, leadership styles, and ultimately leading employees in a health oriented way.
\end{abstract}

\section{Keywords:}

leadership, health-oriented leadership, leadership styles

JEL Classification: M12, I15 